\title{
調査研究委員会レポート
}

\section{原子カ·放射線の知識と防護技術の普及とその手法の開発に関する 技術調査専門委員会}

\author{
委員長 飯本 武志, 幹 事 島添 健次, 佐藤 泰
}

\section{1. 当委員会の設置目的}

2008 年に文部科学省学習指導要領が改訂され，関連指針 に「放射線」の用語が約 40 年ぶりに復活，いわゆる義務教 育における放射線教育が 2012 年に正式に再開された。また 2011 年 3 月，東電・福島第一原発事故が起こり，放射線影 響や放射線がもつ特性について国民の関心が高まった。ま た，関心は放射線分野にとどまらず，原子力関連施設の安 全性, 将来に向けてのエネルギーセキュリティの議論にも 広がっており,さらに活発化している。これらが大きな背 景となり，昨今の原子力・放射線教育界をとりまく社会的 環境は劇的に変わったといえる。

この動きは国内にとどまらず，国際原子力機関 IAEA も， 特に原子力エネルギー新興国を対象とした関連の動きを開 始している。たとえば, RAS0065 TC Project: Specialist advisory meeting for the development of a portfolio of extra-curricular activities for secondary schools on nuclear science and technology (19-22 November, 2013, VIC, Vienna, Austria）である。これは IAEA の 4 年間プロ

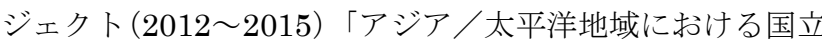
原子力研究機関の持続性とネットワーク化の支援活動」の 一環の活動である。本会議へは日本，韓国，インド，豪州， 英国，米国，イスラエル，フィンランドおよび IAEA の担 当者が参加している。この活動では原子力分野の長期的な 視野での人材育成を目的とし, 中高校生（セカンダリー・ スクール）を対象とした教育プログラムについて，原子力 科学技術分野 (NST) に限ることなく, 科学技術・工学・ 数学（STEM）を網羅する教育内容とし，科学全体に魅力 と興味を感じる土台を作ることを基軸としている。2014 年 には，インドネシア，フィリピン，マレーシア，UAEの 4 か国をパイロット国として選抜し，ここで議論された試験 プログラムの実地運用展開事業を開始したところである。

http://www.iaea.org/newscenter/news/inspiring-highschool-students-pursue-careers-nuclear-science

このような若年層への原子力・教育の必要性はもちろん のこと，原子力・放射線分野に直接に関与寸るメンバー（同 分野の専門家，放射線等のユーザーのみならず，自衛隊， 消防，警察など）の人材育成も並行して重要である。たと えば，大きな事故を受けての放射線防護体系に関する枠組 みを再検討する国内外の動きは激しく，また，防護のツール となる現場における放射線防護技術の開発もめざましい。 これらの近況に関する動向調査に関する期待はきわめて大 きい。この活動は前述の国内外の状況に鑑み，当該分野の 基盤の強化と将来の発展に直結寸るものといえる。その成 果は教育や人材育成にかかわる各方面の研究者, 実務者, さらには，CSR を推進する組織にとっても有意義となろう。

本専門委員会では，これら国内外の動向を背景に，放射 線・放射能に関する正確な知識を普及させることが無用な
混乱を防ぎ過度な対応の抑制につながること, また適切な 防護技術の利用により被曝を防ぐことが重要であること， 等の認識に立ち，次のような調査を行っている。

（1）震災前後の日本における原子力・放射線教育に対す る国民，業界，政府等の考え方や対応，ツールやプ ログラムの変化について関係者間が情報を持ち寄 り，精査すること

（2）放射線防護体系に関寸る枠組みを再検討する国内 外の動きを調査し, 現場における放射線防護技術の 開発状況を調査，整理すること

（3）国際的な原子力・放射線教育（一般国民向け，専門 家育成）に関する動向と実践例を入手し整理するこ と

2. これまでの活動（主に講演）の概要

(a) 教育と人材育成に関する状況調査

・IAEA-RAS0065 TC の活動 飯本（東大）

・日本アイソトープ協会の活動 須藤 (RI 協会)

・放射線教育フォーラムの活動 宮川（原燃）

- 放射線教育推進委員会の活動 掛布（科技振財団）

・原子力人材育成ネットワークの活動 村上 (JAEA)

・原子力安全技術センターの活動 吉田 (NUSTEC)

（b）最新の防護技術に関する状況調査

- 福島第一原子力発電所における放射線防護／安全管理 に関する現場対応の現状 平（東電）

- 空間線量率の三次元的評価の最新技術 島添（東大）

- 廃炉事業の概要と防護技術開発の期待 鈴木（技研組 合)

\section{3. 今後の調査範囲}

調査の範囲を小中高における学校教育と社会人教育及び 専門家の育成に絞り整理を進めることになった。

<小中高における学校教育 $>$

・福島県の活動 ・原子力文化財団の支援活動

- 原産協会の支援活動 - 日本原子力学会の支援活動

<社会人教育及び専門家の育成 $>$

・日本アイソトープ協会の活動 ・技術士協会の活動

- 放射線医学総合研究所の活動・医学物理学会の活動

- 原子力安全研究協会の活動

委 員 長 飯本武志 (東京大)

委員会構成メンバ

委員 井口哲夫 (名古屋大), 伊藤敏明 (東芝) 河原林順（東京都市大），小池正記（広島工大） 越水正典（東北大），笨 武二（筑波大） 坂佐井馨 (原子力機構), 佐々木慎一 (高工研) 柴田裕実（大阪大），高崎浩司（原子力機構） 高田真志（防衛大），高橋浩之（東京大） 田所孝広（日立），野瀨裕之 (IHI) 持木幸一（東京都市大），山田崇裕（RI 協会）

幹事島添健次（東京大）

幹 事 補 佐藤 泰 (産総研) 